Original article

\title{
Polymorphism of genes associated with increased cardiovascular risk and cognitive function in patients with chronic heart failure and in healthy persons: the pilot study
}

\author{
Tatyana V. Martynovich ${ }^{1}$, Natalya S. Akimova ${ }^{1}$, Edward A. Fedotov ${ }^{2}$, Yuri G. Schwartz ${ }^{1}$ \\ ${ }^{1}$ Saratov State Medical University n.a. V.I. Razumovsky, Saratov, Russia \\ ${ }^{2}$ LLC Medical Di center, Saratov, Russia
}

Received 15 December 2014, Accepted 25 December 2014

(C) 2014, Martynovich T.V., Akimova N.S., Fedotov E.A., Schwartz Y.G.

(C) 2014, Russian Open Medical Journal

Abstract: There was studied the relationship between polymorphic variants of APOC3 ( $r$ 2854117), PON1 (rs854560, rs662), AGT (rs4762, rs699) and AGTR1 (rs5186) genes with the results of cognitive tests in patients with chronic heart failure (CHF) of ischemic genesis and healthy persons. The general group included 50 patients with CHF of II-IV functional classes, the control group - 50 healthy volunteers. Cognitive functions were estimated by $5^{\text {th }}$ and $7^{\text {th }}$ subtests of Wexler and Burdon's test. There was revealed statistically significant correlation between the polymorphism of APOC3, PON1, AGT, AGTR1 genes and the results of cognitive tests in patients with CHF and healthy persons. These data suggest that the polymorphism of the studied genes may be important in the genetic susceptibility to the formation and progression of cognitive disorders.

Keywords: polymorphism of genes, chronic heart failure, cognitive disorders

Cite as Martynovich TV, Akimova NS, Fedotov EA, Schwartz YG. Polymorphism of genes associated with increased cardiovascular risk and cognitive function in patients with chronic heart failure and in healthy persons: the pilot study. Russian Open Medical Journal 2015; 4: e0102.

Correspondence to Tatyana V. Martynovich. Address: Department of Faculty Therapy, Saratov State Medical University n.a. V.I. Razumovsky, 112, Bolshaya Kazachia str., 410012, Saratov, Russia. Tel.: +79873376657. E-mail: martynovich-t@mail.ru.

\section{Introduction}

Today a great emphasis is put on the question of cognitive impairments in patients with various neurological and somatic disorders. And a high incidence of cognitive failures and their unavoidable after-effects, such as worsening of life quality and decrease of proper treatment, display interdisciplinary origin of the problem, and the need of early diagnostics of cognitive disorders by doctors of any specialization. According to O.S. Levin's data about 3 million people in Russia suffer from dementia, and more than 18 million people are likely to have moderate cognitive impairments $(\mathrm{MCl})$ [1]. Besides, ageing of population in the developed countries makes the problem of early diagnostics and correction of cognitive failures more actual.

Obviously, that the incidence and severity of cognitive impairments vary depending on the age, which, in particular, is associated with a physiological reduction in the activity of dopaminergic and noradrenergic mediation. Old age is the strongest and independent risk factor of developing of the higher brain functions impairment. It is necessary to be noted that the research of population on the incidence and possible causes of the development of cognitive impairments are chiefly carried among persons of old age, and the results display predominant neurodegenerative origin of brain disorder and frequent detection of dementia $[2,3]$. But we think that the group of patients of middle age presents more interest. In this group light and moderate cognitive impairments are brought to the foreground, they may be corrected to a certain extent and as a result may prevent the development of dementia. Taking into account high incidence of cardiovascular diseases among the patients of this group, the study of evidence of cognitive failures in patients with coronary artery disease (CAD) and chronic heart failure (CHF) is one of the most perspective areas for research. As we know, the presence of cognitive impairments in this group of patients worsens the course and prognosis of the disease, but at the same time the progress of a cardiovascular pathology stimulates the increase of cognitive failures presentation and formation of dementia [4, 5].

Recently we have studied the evidence of cognitive impairments in patients with $\mathrm{CHF}$ of ischemic genesis. It was found out that cognitive functions of the patients depend on severity of $\mathrm{CHF}$ and evidence of atherosclerotic process, with the involvement of the head and neck arteries [6]. In addition, we identified a number of statistically significant correlations between the results of cognitive tests and polymorphic variants of APOC3 and PON1 genes encoding proteins transporters of lipids, and of AGT and AGTR1 genes, encoding proteins of renin-angiotensin-aldosterone system [7-10]. Similar results were not mentioned in the literature before. If the strong effect of $\mathrm{CHF}$ and atherosclerosis on the results of cognitive tests can be explained by the worsening of brain perfusion, clinical and prognostic value of polymorphism of genes in cognitive functions is still not clear. On the one hand point mutation of these genes can lead to cardiovascular pathology developing, what has a negative impact on a cognitive 
status of patients. However, there may be a direct effect of the final products of these genes on the central nervous system and its functions. So, we think it expedient to keep studying the impact of polymorphism of APOC3, PON1, AGT and AGTR1 genes on cognitive functions not only in patients with $\mathrm{CHF}$ of ischemic genesis, but also in persons without any cardiovascular and neurological pathology.

It is necessary to note that earlier some scientists have tried to denote the role of polymorphism of genes in cognitive impairments developing, but such studies included patients with evident psycho-neurological pathology, as Alzheimer's disease, schizophrenia, etc. [11]. Besides, there had been studied polymorphism of genes influencing only on dopaminergic and serotonin systems $[12,13]$. Nevertheless, the results we have got earlier can display the ability of polymorphism of genes impact on various kinds of metabolism in brain neurons, which, finally, predisposes cognitive deficiency developing. We considered it possible to start with a small sampling, as this method is widely spread in pilot studies of such questions $[14,15]$.

Purpose: to study the relationship between polymorphic variants of APOC3, PON1, AGT and AGTR1 genes with cognitive functions in patients with $\mathrm{CHF}$ of ischemic genesis and in healthy persons.

\section{Material and Methods}

The general group included 50 patients with CHF of II-IV functional classes accompanied by CAD, aged from 45 to 65 years (average age 55.7 years). The criteria for the exclusion were acute and sub-acute forms of the ischemic heart disease (IHD), severe somatic pathology, that can give its own effect on the development of the cognitive deficiency, particularly, diabetes mellitus, acute disturbance of cerebral blood circulation in past history, hemodynamically significant stenoses and atherosclerotic plaques of the arteries of the head and the neck (according to duplex ultrasound investigation), dementia features defined by mini mental score examination scale (MMSE).

The control group included 50 healthy volunteers aged from 20 to 25 years (average age 21.5 years). The age of the control group was chosen according to the following reasons. The literature data display that at the age of 20-25 years cognitive functions achieve maximal point of developing, besides, persons from this age group have minimal risk of cognitive disorders progress (vascular defect, neurodegenerative processes in brain, tumors, etc.) [16]. We consider that such control group responds to the aim of the given study, as it excludes mediated impact of the studied genes on cognitive functions by vascular pathology.

Taking into account individuality of a genetic structure of different populations, the study included only unrelated persons of Caucasian race, living in Saratov and Saratov region.

Cognitive functions were estimated by $5^{\text {th }}$ and $7^{\text {th }}$ subtests of Wexler and Burdon's test. Operative memory and attention, visual-motion learning, shifting of an attention and detracting were estimated by these tests. The choice of these tests is conditioned by their popularity and simplicity [13]. Besides, in recent studies we have shown an efficiency of using the tests in diagnostics of $\mathrm{MCl}$ in patients with $\mathrm{CHF}$ of ischemic genesis. The comparison of different results of cognitive tests in carriers of various studied polymorphic genes have been performed separately both in the group of the patients with CHF and in healthy persons.
Table 1. Characteristics of polymorphic variants of the studied genes

\begin{tabular}{|c|c|c|c|c|}
\hline Gene & Protein & $\begin{array}{c}\text { Polymorphic } \\
\text { locus }\end{array}$ & rs & Genotypes \\
\hline APOC3 & Apolipoprotein C3 & $-482 C>T$ & rs2854117 & $\mathrm{CC}, \mathrm{CT}, \mathrm{TT}$ \\
\hline \multirow{2}{*}{ PON1 } & \multirow{2}{*}{ Paraoxonase 1} & L55M A $>T$ & rs854560 & AA, AT, TT \\
\hline & & Q192R A > G & rs662 & $\mathrm{AA}, \mathrm{AG}, \mathrm{GG}$ \\
\hline \multirow{2}{*}{ AGT } & \multirow{2}{*}{ Angiotensinogen } & T174M C>T & rs4762 & $\mathrm{CC}, \mathrm{CT}, \mathrm{TT}$ \\
\hline & & M235T T>C & rs699 & $\mathrm{TT}, \mathrm{TC}, \mathrm{CC}$ \\
\hline AGTR1 & $\begin{array}{c}\text { Receptor } 1 \text { of } \\
\text { angiotensin II type }\end{array}$ & $\mathrm{A} 1666 \mathrm{C} A>C$ & rs5186 & $\mathrm{AA}, \mathrm{AC}, \mathrm{CC}$ \\
\hline
\end{tabular}

Table 2. Distribution of frequencies of genotypes in the studied and in the control groups

\begin{tabular}{|c|c|c|c|c|c|}
\hline \multirow[t]{2}{*}{ Gene } & \multirow[t]{2}{*}{ Polymorpism } & \multirow[t]{2}{*}{ Genotype } & \multicolumn{2}{|c|}{$\begin{array}{c}\text { Distribution of genotypes, } \\
\text { no. (\%) }\end{array}$} & \multirow[t]{2}{*}{$\chi^{2}$} \\
\hline & & & Patients & Healthy & \\
\hline \multirow{3}{*}{ АРОС } & \multirow{3}{*}{$-482 C>T$} & $\mathrm{CC}$ & $25(50)$ & $25(50)$ & \multirow{3}{*}{22.3} \\
\hline & & $\mathrm{CT}$ & $21(42)$ & $18(36)$ & \\
\hline & & TT & $4(8)$ & $7(14)$ & \\
\hline \multirow{6}{*}{ PON1 } & \multirow{3}{*}{ L55M A $>\mathrm{T}$} & AA & $27(54)$ & $29(58)$ & \multirow{3}{*}{24.5} \\
\hline & & AT & $16(32)$ & $16(32)$ & \\
\hline & & TT & $7(14)$ & $5(10)$ & \\
\hline & \multirow{3}{*}{ Q192R A>G } & AA & $21(42)$ & $28(56)$ & \multirow{3}{*}{24.4} \\
\hline & & $A G$ & $19(38)$ & $22(44)$ & \\
\hline & & GG & $10(20)$ & $0(0)$ & \\
\hline \multirow{6}{*}{ AGT } & \multirow{3}{*}{$\mathrm{T} 174 \mathrm{M} \mathrm{C}>\mathrm{T}$} & $\mathrm{CC}$ & $33(66)$ & $29(58)$ & \multirow{3}{*}{25.5} \\
\hline & & $\mathrm{CT}$ & $15(30)$ & $20(40)$ & \\
\hline & & $\mathrm{TT}$ & $2(4)$ & $1(2)$ & \\
\hline & \multirow{3}{*}{ M235T T>C } & $\mathrm{TT}$ & $26(52)$ & $12(24)$ & \multirow{3}{*}{25.3} \\
\hline & & TC & $11(22)$ & $32(64)$ & \\
\hline & & $\mathrm{CC}$ & $13(26)$ & $6(12)$ & \\
\hline \multirow{3}{*}{ AGTR1 } & \multirow{3}{*}{$\mathrm{A} 1666 \mathrm{C} A>C$} & $A A$ & $26(52)$ & $31(62)$ & \multirow{3}{*}{25.6} \\
\hline & & $A C$ & $23(46)$ & $17(34)$ & \\
\hline & & $\mathrm{CC}$ & $1(2)$ & $2(4)$ & \\
\hline
\end{tabular}

Polymorphic variants of APOC3 -482 C $>$ T (rs2854117), PON1 L55M A>T (rs854560), PON1 Q192R A>G (rs662), AGT T174M C>T (rs4762), AGT M235T T>C (rs699) and AGTR1 A1666C A>C ( rs5186) genes were identified using the system of genetic analysis "PyroMark Q24". The characteristics of polymorphic variants of studied genes are presented in Table 1.

Method of factorial dispersion analysis "ANOVA" by the program Statistica-7 was used, after the test of normalcy of distribution. To avoid the problem of multiple comparisons there was used Kruskal-Wallis test for the number of independent samplings.

Genotypes with the presence of the mutant allele (homozygote and heterozygote) were combined into one group, and wild homozygotes - into another one.

\section{Results}

The distribution of the frequencies of genotypes of the studied genes in patients with CHF of ischemic genesis and in healthy persons is presented in Table 2. The established distribution of genotypes corresponded to expected distribution inclusive of Hardy-Weinberg equilibrium. 
Table 3. Results of cognitive tests depending on polymorphism of the studied genes in patients with CHF of ischemic genesis (M $\pm S D$ )

\begin{tabular}{|c|c|c|c|c|c|}
\hline Gene & Genotypes & Attentiveness & Speed & Accuracy & Wechsler 5 \\
\hline \multirow{2}{*}{$\begin{array}{c}\text { APOC3 } \\
-482 \text { C }>\text { T }\end{array}$} & CC & $0.81 \pm 0.21^{*}$ & $99.78 \pm 20.71 *$ & $2.99 \pm 3.47$ & $9.87 \pm 1.93$ \\
\hline & $\mathrm{CT}+\mathrm{TT}$ & $0.88 \pm 0.12 *$ & $114.99 \pm 22.23 *$ & $2.89 \pm 2.41$ & $9.33 \pm 1.66$ \\
\hline \multirow{2}{*}{$\begin{array}{c}\text { PON1 } \\
\text { L55M A }>T\end{array}$} & $\mathrm{AA}$ & $0.90 \pm 0.07 *$ & $113.43 \pm 21.41$ & $3.39 \pm 2.67$ & $10.0 \pm 2.12$ \\
\hline & $\mathrm{AT}+\mathrm{TT}$ & $0.83 \pm 0.12^{*}$ & $109.50 \pm 24.21$ & $2.43 \pm 3.06$ & $9.44 \pm 1.50$ \\
\hline \multirow{2}{*}{$\begin{array}{c}\text { PON1 } \\
\text { Q192R A>G }\end{array}$} & AA & $0.92 \pm 0.04 *$ & $110.08 \pm 24.27$ & $3.50 \pm 3.79$ & $10.57 \pm 2.51^{*}$ \\
\hline & $A G+G G$ & $0.85 \pm 0.10^{*}$ & $118.57 \pm 10.13$ & $2.51 \pm 1.92$ & $9.56 \pm 1.68^{*}$ \\
\hline \multirow{2}{*}{$\begin{array}{c}\text { AGT } \\
\text { T174M C>T }\end{array}$} & CC & $0.90 \pm 0.07^{*}$ & $114.56 \pm 22.53$ & $3.57 \pm 3.24$ & $10.08 \pm 1.87^{*}$ \\
\hline & $\mathrm{CT}+\mathrm{TT}$ & $0.79 \pm 0.18^{*}$ & $105.35 \pm 22.18$ & $1.59 \pm 1.06$ & $9.07 \pm 1.71 *$ \\
\hline \multirow{2}{*}{$\begin{array}{c}\text { AGT } \\
\text { M235T T>C }\end{array}$} & $\mathrm{TT}$ & $0.94 \pm 0.07^{*}$ & $122.08 \pm 23.39 *$ & $3.25 \pm 3.65$ & $10.33 \pm 1.67$ \\
\hline & $\mathrm{TC}+\mathrm{CC}$ & $0.82 \pm 0.16^{*}$ & $107.06 \pm 21.04 *$ & $2.79 \pm 2.52$ & $3.48 \pm 1.91$ \\
\hline
\end{tabular}

$*^{*}$ - statistically significant pairs differences $(\mathrm{p}<0.05)$.

Table 4. Results of cognitive tests depending on polymorphism of the studied genes in healthy persons (M $\pm S D$ )

\begin{tabular}{|c|c|c|c|c|c|}
\hline Gene & Genotypes & Attentiveness & Speed & Accuracy & Wechsler 5 \\
\hline \multirow{2}{*}{$\begin{array}{c}\text { APOC3 } \\
-482 \text { C }>\mathrm{T}\end{array}$} & CC & $0.91 \pm 0.09 *$ & $181.11 \pm 24.16$ & $4.75 \pm 4.37$ & $11.17 \pm 1.29$ \\
\hline & $\mathrm{CT}+\mathrm{TT}$ & $0.85 \pm 0.14 *$ & $174.99 \pm 27.36$ & $4.53 \pm 4.96$ & $10.33 \pm 2.89$ \\
\hline \multirow{2}{*}{$\begin{array}{c}\text { PON1 } \\
\text { L55M A>T }\end{array}$} & AA & $0.90 \pm 0.10$ & $182.09 \pm 26.05$ & $4.54 \pm \pm 4.56$ & $11.63 \pm 1.16^{*}$ \\
\hline & $\mathrm{AT}+\mathrm{TT}$ & $0.89 \pm 0.10$ & $173.59 \pm 25.28$ & $4.73 \pm 4.81$ & $9.69 \pm 2.81^{*}$ \\
\hline \multirow{2}{*}{$\begin{array}{c}\text { PON1 } \\
\text { Q192R A>G }\end{array}$} & $\mathrm{AA}$ & $0.92 \pm 0.07^{*}$ & $172.52 \pm 26.59^{*}$ & $3.68 \pm 4.25^{*}$ & $9.99 \pm 2.72 *$ \\
\hline & $A G+G G$ & $0.96 \pm 0.05 *$ & $184.42 \pm 23.71^{*}$ & $5.77 \pm 4.91 *$ & $11.63 \pm 1.15^{*}$ \\
\hline \multirow{2}{*}{$\begin{array}{c}\text { AGT } \\
\text { T174M C>T }\end{array}$} & $\mathrm{CC}$ & $0.89 \pm 0.07^{*}$ & $177.49 \pm 24.28$ & $3.59 \pm 3.42^{*}$ & $10.43 \pm 2.59$ \\
\hline & $\mathrm{CT}+\mathrm{TT}$ & $0.93 \pm 0.10 *$ & $178.67 \pm 28.55$ & $6.21 \pm 5.28^{*}$ & $11.21 \pm 1.67$ \\
\hline \multirow{2}{*}{$\begin{array}{c}\text { AGT } \\
\text { M235T T>C }\end{array}$} & $\mathrm{TT}$ & $0.90 \pm 0.08$ & $183.71 \pm 26.88$ & $3.38 \pm 2.67$ & $11.00 \pm 1.32$ \\
\hline & $\mathrm{TC}+\mathrm{CC}$ & $0.90 \pm 0.11$ & $175.98 \pm 25.47$ & $5.07 \pm 5.09$ & $10.65 \pm 2.53$ \\
\hline \multirow{2}{*}{ AGTR1 A1666C A>C } & $\mathrm{AA}$ & $0.84 \pm 0.14 *$ & $177.17 \pm 26.13$ & $4.14 \pm 4.83$ & $11.09 \pm 1.41$ \\
\hline & $A C+C C$ & $0.94 \pm 0.05 *$ & $179.15 \pm 25.88$ & $5.39 \pm 4.36$ & $10.21 \pm 3.15$ \\
\hline
\end{tabular}

* - statistically significant differences $(p<0,05)$.

There were not revealed the statistically significant correlations between polymorphic variants of studied genes and myocardial infarction, functional classes of $\mathrm{CHF}$, the expulsion fraction of the left ventricle and heart cavity sizes determining in Doppler imaging during factorial dispersion analysis in patients with CHF. But there was revealed the association between the results of cognitive tests with the polymorphic variants of APOC3, PON1, AGT and AGTR1 genes both in the main and control groups. In addition, it draws attention to the different effects of the risk alleles of these genes on the results of cognitive tests of the patients from the general and control groups. Thus, the risk allele of gene APOC3 $-482 \mathrm{C}>\mathrm{T}$ (genotypes $\mathrm{CT}+\mathrm{TT}$ ) was connected with the worsening of attentiveness in healthy persons, and, quite the opposite, with improving of Bourdon's test results in patients with CHF of ischemic genesis.

Mutation of PON1 gene, especially in Q192R A>G position, in patients with $\mathrm{CHF}$ was associated with a worsening of attentiveness and operative memory according to the 5th Wexler subtest. In addition, results of cognitive tests in the group of healthy people were better than in carriers of mutant allele of this gene.

Polymorphic variants $174 \mathrm{M}$ and $235 \mathrm{~T}$ of AGT gene are associated with worsening of Bourdon's test and $5^{\text {th }}$ Wexler subtest in patients with CHF. There were no statistically significant correlations between polymorphism of AGTR1 gene and cognitive functions in patients with CHF. Opposite results were noted in the group of healthy persons. Mutation of AGT T174M C>T gene was associated with improving of cognitive tests, that is concentration of attention and precision of Bourdon's test performance. Also correlation between mutant allele C of AGTR1 A1666C A>C gene and improving of attentiveness in healthy persons were identified. The general results of this analysis are presented in Tables 3 and 4 .

\section{Discussion}

The obtained results confirm the established relationships between polymorphism of APOC3, PON1, AGT and AGTR1 genes with results of cognitive tests in patients with $\mathrm{CHF}$ of ischemic genesis $[7,8]$. Correlations between polymorphism of these genes and cognitive functions of healthy persons have been revealed for the first time. This fact partially confirms our hypothesis of a direct influence of final products of the studied genes on brain neurons metabolism, and this can predispose developing of cognitive deficiency in cardiac patients and in healthy population.

It is not an unexpected connection of polymorphism of APOC3 and PON1 genes encoding proteins transporters of lipids with cognitive functions of the patients from both of the studied groups, taking into account an important role of lipid metabolism in constitution and functioning of the central nervous system. We think that the most interesting fact is the different results of actions of these genes' mutation on cognitive functions in patients with CHF and healthy persons. As we know, mutation of APOC3 $-482 \mathrm{C}>\mathrm{T}$ gene is associated with increased triglycerides, LDL - cholesterol and apolipoprotein B, which can cause atherosclerosis progression and have a negative impact on cognitive functions of patients, predisposing to cognitive deficiency [17]. Although, it should be noted 
that our study included healthy persons and patients with $\mathrm{CHF}$ without hemodynamically significant cerebral atherosclerosis. Meanwhile, with cardiovascular pathology and probably chronic brain ischemia, high concentration of atherogenic lipoproteins, associated with allele of risk T APOC3 -482 C>T gene, has some protective impact on metabolic processes in brain and cognitive functions in patients with CHF. This supposition confirms to some degree the results we have received earlier: worsening of memory and attention in patients with CHF with decrease of atherogenic cholesterol fractions, and also findings of other authors displaying worsening of cognitive tests with decreasing of total cholesterol and LDL-cholesterol in blood [18].

The correlation of polymorphism of PON1 (L55M A>T and Q192R $A>G$ ) gene with cognitive functions in patients with $C A D$, is probably mediated not only by impact of this gene on lipid metabolism by the increase of atherogenic cholesterol fractions and LDL peroxidation, but also by paraoxonase features to flexible hydrolysis of toxic organo-phosphorous metabolites which may have negative impact on brain and its functions [19]. The latter is more interesting for the group of patients of middle age with CHF who has had one or more episodes of intoxication of various origins. We can suppose that change of paraoxonase activity connected with mutation of PON1 gene, may play a diverse role in developing of cognitive dysfunction in persons with CHF of ischemic genesis. Taking the above into account, the reason of relevant decrease of results of cognitive tests in healthy group, having also mutants of the studied genes, is not determined.

As to AGT and AGTR1 genes, influencing on the activity of one of the main neurohumoral systems, revealing their connection with the results of cognitive tests not only in patients with CHF, but in healthy persons, is unexpected to some degree and need to be studied further to understand its impact on central nervous system. We can suppose that even imperceptible increase of vasoactive hormones of the renin-angiotensin-aldosterone system in healthy persons connected with mutation of the mentioned genes may be the reason of activation of adaptive mechanisms, as increase of cerebral and coronary blood flow, which can improve cognitive functions. Conversely, long pathological hyperactivation of this humoral system is typical to patients with CHF and CAD and has a negative impact on brain functions because of a constant and immoderate arteriole spasms, edema syndrome developing and wide spectrum of metabolic failures, which may cause cognitive dysfunction progress.

Thus, APOC3, PON1, AGT and AGTR1 genes are associated with the severity of cognitive dysfunction both in patients with $\mathrm{CHF}$ of ischemic genesis and in healthy persons. Determining of their polymorphic variants may cause an early revealing of underlying risk for cognitive deficiency.

\section{Conclusion}

In conclusion it is necessary to be noted that these results should be evaluated with account of all known problems with analysis of point mutations and their role in genetic underlying for multifactorial diseases developing. In particular, the problem of estimation of a supposed contribution of genetic component into multifactorial diseases developing and paradox of "missing" ("disappearing") heredity must be considered. Unfortunately, today it is possible to denote only a group of risk of multifactorial diseases, but not to forecast the risk of individual multifactorial diseases on the base of genetic analysis [20, 21]. Certainly, it is necessary to keep studying the value of polymorphism of the presented and studied genes, as well as epimutations in developing of cognitive failures in patients with $\mathrm{CHF}$ and in healthy persons on the whole.

\section{Conflict of interest: none declared.}

\section{References}

1. Levin OS. Diagnosis and treatment of dementia in clinical practice. Moscow: MEDpress-inform, 2010; 256 p. Russian

2. Lokshina $A B$, Zaharov VV. Cognitive impairments in clinical practice. Vrach 2009; (4): 21-25. Russian

3. Yakhno NN, Lavrov AYu. Changes in the central nervous system in ageing. Neurodegenerative diseases and ageing: Manual for doctors. I.A. Zavalishin, N.N. Yahno, S.I. Gavrilova eds. Moscow, 2001: 242-261. Russian

4. Morozova TE, Rykova SM. Cardiovascular disease and cognitive impairment. Consilium Medicum 2010; 12(9): 85-89. Russian

5. De Leeuw FE, van Gijn J. Vascular dementia. Pract Neurol 2003; 3: 8691. (doi: 10.1046/j.1474-7766.2003.04132.x)

6. Akimova NS, Persashvili DG, Martynovich TV, Schwartz YG. Cognitive disorders and the condition of the gray matter of the brain in chronic heart failure on the background of CHD. Zhurnal serdechnaya nedostatochnost' 2011; 12(5): 282-285. Russian

7. Martynovich TV, Akimova NS, Aristarin MA. The relationship of cognitive functions with polymorphism of ABCA1, APOC3 and PON1 genes in patients with chronic heart failure of ischemic genesis. Bulletin of Medical Internet Conferences 2014; 4(3): 231. Russian

8. Martynovich TV, Akimova NS, Aristarin MA. The relationship of polymorphism of ABCA1, APOC3 and PON1 genes with the severity of atherosclerosis and chronic heart failure in patients with ischemic heart disease. Bulletin of Medical Internet Conferences 2014; 4(3): 230 Russian

9. Martynovich TV, Akimova NS, Svarts YG. The relationship between the severity of chronic heart failure with polymorphism of ADRB2, AGTu AGTR1 genes in patients with ischemic heart disease. In: Materials of the III all-Russian conference "the Contradictions of modern cardiology: a controversial and unresolved issues". Samara, November 7-8, 2014: 146. Russian

10. Martynovich TV, Akimova NS, Svarts YG. The relationship between polymorphism of ADRB2 and AGT genes with the severity of the brachiocephalic artery atherosclerosis and cognitive impairments in patients with chronic heart failure. In: Materials of the III all-Russian conference "the Contradictions of modern cardiology: a controversial and unresolved issues". Samara, November 7-8, 2014: 147. Russian

11. Mengel-From J, Thinggaard $M$, Lindahl-Jacobsen $R$, McGue $M$, Christensen K, Christiansen L. CLU genetic variants and cognitive decline among elderly and oldest old. PLoS One 2013; 8(11): e79105. (doi: 10.1371/journal.pone.0079105) (PMID: 24244428) (PMCID: PMC3828341)

12. Golimbet VE, Lebedeva IS, Gritsenko IK, Korovaĭtseva GI, Alfimova MV, Lezheǐko TV, et al. A study of some genes related to serotoninergic and dopaminergic systems and auditory evoked-potentials (P300) in patients with schizophrenia and spectrum disorders and their firstdegree relatives. Zh Nevrol Psikhiatr Im S S Korsakova 2005; 105(10): 35-41. Russian (PMID: 16281377)

13. Ostroumova OD, Desnitskaya IV. Rosuvastatin impact on cognitive functions. Consilium Medicum 2007; 1(2): 61-63. Russian

14. Mormol' IA. Pharmacogenetic aspects of candesartan application for the treatment of arterial hypertension in patients with chronic pyelonephritis. Lik Sprava 2014; (3-4): 119-125. (PMID: 25286611)

15. Rodríguez R, Guerrero D, Rivas Y, Lacruz A, Flores Y. Genetic variations of beta-MYH7 in Venezuelan patients with hypertrophic cardiomyopathy. Invest Clin 2014; 55(1): 23-31. (PMID: 24758099) 
16. Zaharov VV, Yahno NN. Memory impairments. Moscow, Russia: GEOTAR-MED, 2003; 157 p. Russian

17. Talmud PJ, Hawe E, Martin S, Olivier M, Miller GJ, Rubin EM, et al. Relative contribution of variation within the APOC3/A4/A5 gene cluster in determining plasma triglycerides. Hum Mol Genet 2002; 11(24): 3039-3046. (PMID: 12417525) (doi: 10.1093/hmg/11.24.3039)

18. Lee PH, Lim TS, Shin HW, Yong SW, Nam HS, Sohn YH. Serum cholesterol levels and the risk of multiple system atrophy: a casecontrol study. Movement Disorders 2009; 24(5): 752-758. (PMID: 19185013) (doi: 10.1002/mds.22459)

19. Hassan MA, Al-Attas OS, Hussain T, Al-Daghri NM, Alokail MS, Mohammed AK, Vinodson B. The Q192R polymorphism of the paraoxonase 1 gene is a risk factor for coronary artery disease in Saudi subjects. Mol Cell Biochem 2013; 380(1-2): 121-128. (PMID: 23625196) (doi: 10.1007/s11010-013-1665-z)

20. Baranov VS. Human genome, missng heritability and personal genetic data-bank. Meditsinskaya Genetika 2011; 10(9): 3-10. Russian

21. Novikov PV. DNA-test: monogenic and multifactorial diseases. Russian Medical Journal 2011; 19(12): 794-800. Russian

Authors:

Tatyana V. Martynovich - MD, Assistant Professor, Department of Faculty Therapy, Saratov State Medical University n.a. V.I. Razumovsky, Saratov, Russia.

Natalya S. Akimova - MD, PhD, Assistant Professor, Department of Faculty Therapy, Saratov State Medical University n.a. V.I. Razumovsky, Saratov, Russia.

Edward A. Fedotov - MD, PhD, Head of of laboratory, LLC Medical Di center, Saratov, Russia.

Yuri G. Schwartz - MD, D.Sc., Professor, Head of Department of Faculty Therapy, Saratov State Medical University n.a. V.I. Razumovsky, Saratov, Russia. 